\title{
ІНТЕГРАТИВНИЙ ПОРТРЕТ КОРПОРАТИВНОЇ КУЛЬТУРИ В ЗАКЛАДАХ ОХОРОНИ ЗДОРОВ'Я
}

\author{
О. Н. Литвинова ${ }^{1}$, Н. М. Абашник ${ }^{2}$ \\ ${ }^{1}$ Тернопільський національний медичний університет \\ імені І. Я. Горбачевського МОЗ Украӥни \\ ${ }^{2}$ Комунальне некомерційне підприємство Харківської обласної ради \\ "Обласна клінічна лікарня"
}

\begin{abstract}
У статті наведено інтегративний портрет корпоративної культури у закладах охорони здоров’я в період реформування системи охорони здоров'я. Акцентовано увагу на ключових проблемах корпоративної культури в закладах охорони здоров’я, які потребують вирішення.
\end{abstract}

\section{INTEGRATED IMAGE OF CORPORATE CULTURE IN HEALTHCARE ESTABLISHMENTS}

\author{
O. N. Lytvynova ${ }^{1}$, N. M. Abashnyk ${ }^{2}$ \\ ${ }^{1}$ I. Horbachevsky Ternopil National Medical University \\ ${ }^{2}$ Communal non-profit enterprise of Kharkiv Regional Council «Regional Clinical Hospital»
}

The article presents an integrative image of corporate culture in health care facilities during the reform of the health care system. Emphasis is BASED on the key issues of corporate culture in health care facilities, which need significant refinement.

Вступ. Базова стратегія закладів охорони здоров'я $\epsilon$ першоосновою формування. Міцна та високорозвинена культура сприяє розвитку та зміцненню закладів охорони здоров'я, збільшенню задоволеності потреб пацієнта, підвищенню самооцінки та самодостатності медичного персоналу, а звідси і підвищенню ефективності їх діяльності.

Високий рівень корпоративної культури $\epsilon$ важливим стратегічним чинником, який мобілізує всі структурні ланки медичних установ та їх працівників на досягнення поставлених цілей в рамках задекларованої місії організації. Тому на сьогодні формування інтегративного портрету корпоративної культури $\epsilon$ важливим чинником досягнення успіху в закладах охорони здоров'я [1]. Корпоративна культура закладів охорони здоров'я визначає шлях їх розвитку у сфері управління персоналом. Для того, щоб чітко визначитись із корпоративною культурою в таких закладах, передусім необхідно зважати на їі принципи та визначити основні їх структурні елементи.

Основна частина. Розглядаючи елементи корпоративної культури закладів охорони здоров'я через

(c) О. Н. Литвинова, Н. М. Абашник, 2021 призму окремих її структурних блоків та окремих фрагментів кожного блоку, ми змогли проаналізувати їх та вивести інтегративний портрет такої культури в закладах із погляду середнього медичного персоналу.

Цінність такої інтегративної ролі полягає в тому, що люди усвідомлюють себе часткою єдиного колективу, живуть і діють в ньому, досягають значних результатів. Ступінь такого усвідомлення визначає рівень цінності та продукує ефективність діяльності колективу. Варто звернути увагу на те, що корпоративною культурою об'єднуються люди незалежно від їх світоглядної та ідеологічної орієнтації, національної приналежності, раси тощо. Однак необхідно вважати, що зближення, яке відбувається на основі типової або функціональної спорідненості, може мати і зворотний процес, що призводитиме до конфліктів у колективі.

Вивчаючи корпоративну культуру в закладах охорони здоров'я, ми орієнтувалися на найчисельнішу групу працівників системи - це середній медичний персонал. Саме вони є тим базисом, на якому вибудовуються всі елементи корпоративної культури, 
саме від них залежить мікроклімат у колективі, саме вони формують імідж колективу, виступають його візитівкою [2]. Тому від його активності, позитивності, врівноваженості залежить морально-психологічний клімат і в цілому корпоративна культура закладів.

Аналіз оцінок блоків корпоративної культури дозволив нам вибудувати кумулятивну криву розподілу балів оцінки корпоративної культури в закладах охорони здоров'я (рис. 1).

Для альтернативної гіпотези дослідження брали такі когортні блоки складових корпоративної культури, як іміджеві ознаки, куди входили блоки: «Зовніш- ній вигляд, одяг і представлення себе на роботі», «Цінності та норми» та «Організація харчування співробітників». Другим когортним блоком були комунікаційні ознаки та взаємостосунки: «Комунікаційна система та мова спілкування», «Взаємовідносини між людьми у Вашому колективі», «Усвідомлення себе і свого місця в організації», «Віра у щось і ставлення чи прихильність до чогось». Третім і останнім когортним блоком виступали питання мотивації та дисципліни: «Процес розвитку працівника і навчання», «Трудова етика і вмотивування» та «Усвідомлення часу, ставлення до часу і його використання».

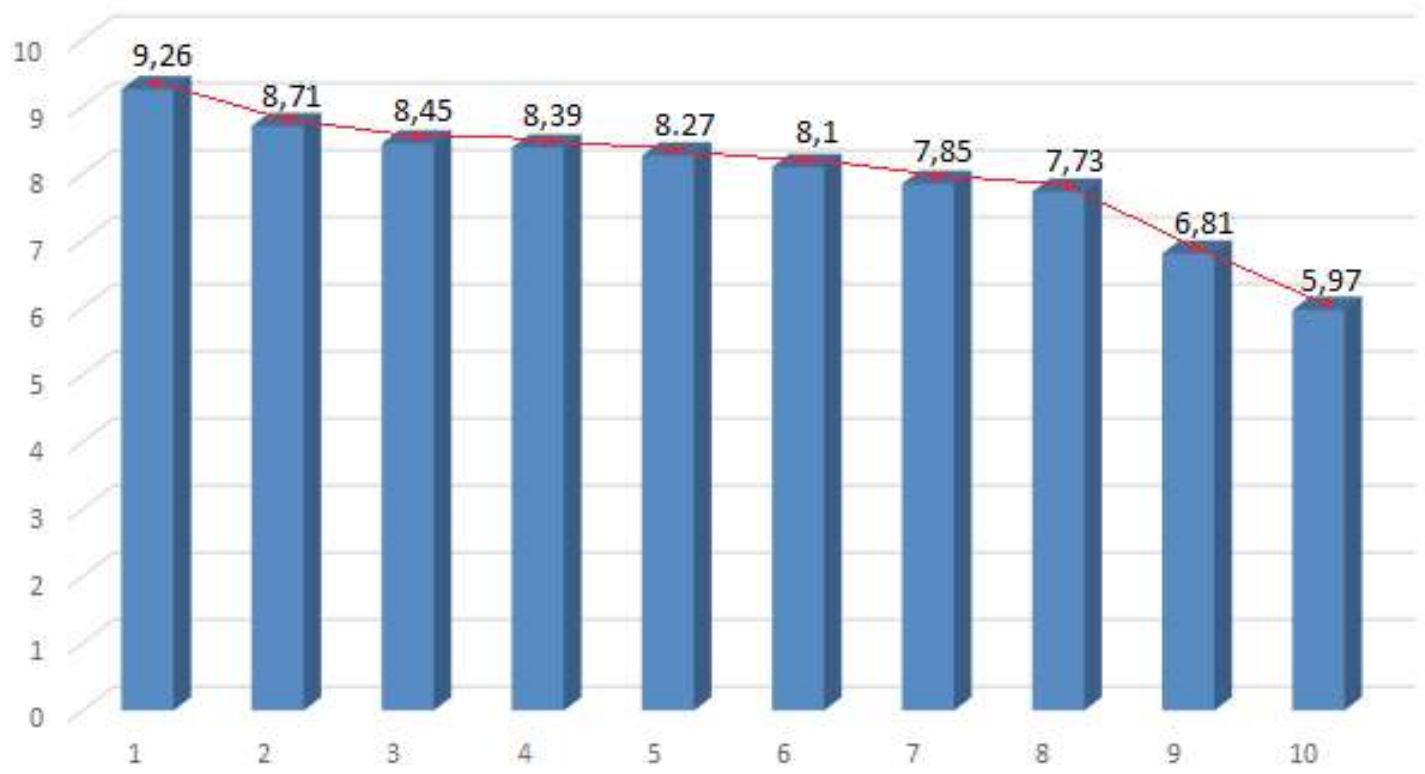

1. Зовнішній вигляд, одяг і представлення себе на роботі - 9,26 2,9.

2. Цінності та норми $-8,71 \pm 2,8$.

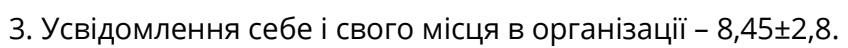

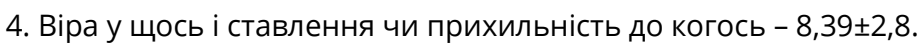

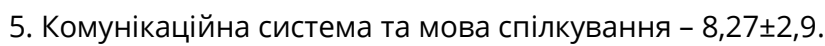

6. Процес розвитку працівника і навчання $-8,1 \pm 2,7$.

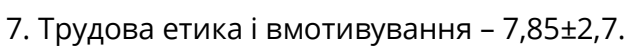

8. Взаємовідносини між людьми у Вашому колективі - 7,73ะ2,7.

9. Усвідомлення часу, ставлення до часу і його використання $-6,81 \pm 2,5$.

10. Організація харчування співробітників $-5,97 \pm 2,4$.

\section{РUC. 1. Кумулятивна крива розподілу балів оцінки корпоративної культури в закладах охорони здоров'я.}

Аналізуючи кумулятивну криву розподілу балів оцінки корпоративної культури в закладах охорони здоров'я, бачимо, що серед усіх складових корпоративної культури «Зовнішній вигляд, одяг і представлення себе на роботі» середній медичний пер-

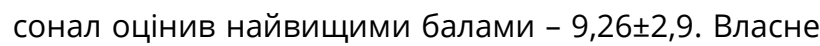
кажучи, ці видимі атрибути вигляду медсестер найнаглядніше показують «лице фірми». Саме цим озна- кам медсестри на практиці приділяють достатньо уваги. Всі інші функції стосуються дисциплінарних проявів. Однією з найважливіших функцій корпоративної культури $є$ передача соціального досвіду, що виявляє ії інформаційну компоненту. У сфері медичної допомоги ці прояви зовнішнього іміджу якраз найкраще ілюструють цей феномен. Стереотипне уявлення про охайний вигляд медсестри у білому 
халаті передається з покоління в покоління і міцно утримується у проявах корпоративної культури закладів охорони здоров'я.

На другому місці за значущістю медсестри поставили «Цінності та норми» $((8,71 \pm 2,8)$ бала). До цього блоку входили вивчення фрагментів взаємовизнання досягнень колег, власний професіоналізм та ставлення до пацієнтів. Цей блок питань засвідчував важливість даних норм та цінностей для діяльності закладів саме медичної допомоги, де поняття співчуття, емпатії, зібраності часом відіграють ключову роль.

Блок «Усвідомлення себе і свого місця в організації» передбачав вивчити «наскільки Ви важливі для колективу» і «наскільки колектив важливий для Вас», що визначало важливість для респондентів приналежності до групи. Як бачимо, ця властивість займає третє місце серед досліджуваних блоків у корпоративній культурі закладу і оцінена респондентами в $(8,45 \pm 2,8)$ бала.

Потреби у приналежності до колективу, групи зазвичай співвідносяться з потребами в спілкуванні, трудовій діяльності, соціально-економічній активності, духовній культурі, тобто у всьому, що є продуктом життя колективу.

Соціальні потреби залежать від специфічних умов діяльності соціальних суб'єктів, зокрема це стосується медичних колективів з усіма їх особливостями та специфіками. Усвідомлення соціальної потреби стає мотивацією діяльності й проявляється бажаннями, цілями, інтересами людей.

В ієрархії потреб за Маслоу соціальні потреби займають третє місце як потреби в соціальних зв'язках. Вони вказують на необхідність соціального єднання з групою і приналежності до неї, соціальних контактів, а також любові, позитивного ставлення 3 боку інших, соціальної взаємодії. Результати нашого дослідження виражено підтвердили цю тезу.

Станіслав Каверін підкреслює необхідність належати до певної соціальної групи і посідати в ній певне місце, користуватись увагою оточуючих, бути об'єктом поваги і любові, а також необхідністю в самоствердженні, пізнанні та самовираженні, що і відзначили респонденти у своїх оцінках.

Наступним мотиваційним чинником, який ми досліджували, $є$ віра. Як відомо, віра - це потужний мотиваційний чинник праці, здійснення мрії та досягнення успіху. Не тільки віра у власні сили, але й спілкування з людьми, які підтримують і надихають, $\epsilon$ необхідною умовою досягнення успіху в будь-якій справі та джерелом звершень.

Віра у власні сили, впевненість у собі - це незаперечна формула успіху. Відсутність впевненості позбавляє людину внутрішньої сили, послаблює життєві позиції. Впевненість у собі - це імунітет проти депресії. Впевнені люди здатні аналізувати складну ситуацію та приймати відповідальні рішення. їх відмітна ознака - постійне задоволення життям і вони майже ніколи не впадають у депресію.

Віра в керівництво передбачає, що його слова і дії правильні, що воно сказало і зробило в даній ситуації саме те, що думала і хотіла зробити сама людина, тому вона впевнена у правильності вибору керівництва.

Віра у колектив тісно пов'язана із проявами взаємодопомоги. Такі відносини цінують за невимушеність, природність, почуття гумору і розкутість у спілкуванні. У такому колективі легше досягти тієї мети, яку він собі поставив, за рахунок рішучості, наполегливості, незалежності, готовності відстояти власну думку, які дає незмінна впевненість у собі та своїх колегах.

Для колективу, який надає медичну допомогу, ці властивості $є$ особливо актуальними і затребуваними, що і підтвердили у своїх відповідях медсестри в процесі вивчення даної властивості «Віра у щось і ставлення чи прихильність до когось», яку вони оцінили у $(8,39 \pm 2,8)$ бала (рис. 1). Дана оцінка засвідчує, що у закладах охорони здоров'я взаємовідносини між персоналом здорові та основані на принципах віри, взаємодопомоги та впевненості у своїх позиціях, що є найнеобхіднішими властивостями при командному наданні допомоги хворим людям.

Комунікаційні компетентності в системі медичної допомоги $є$ невід'ємними вміннями налагоджувати контакти між співробітниками, пацієнтами та їхніми родичами. Саме від вміння прихилити до себе співрозмовника, викликати у нього довіру до себе та своїх переконань залежить результат лікування [3]. Успішна комунікація між вертикальними рівнями співробітників гарантує душевну рівновагу і більше забезпечує безпомилковість прийняття рішень та їх виконання.

Вивчення даної властивості у нашому дослідженні показало, що $є$ ще певні проблеми у цих питаннях. Середній медичний персонал оцінив властивість «Комунікаційна система та мова спілкування» достатньо високим, хоч і не найвищим балом $(8,27 \pm 2,9)$. Отже, в закладах охорони здоров'я, зва- 
жаючи на важливість питань комунікації, потрібно більше уваги приділяти їх удосконаленню і знаходити мотиваційні чинники для їх покращення.

Подальші напрямки дослідження корпоративної культури стосувалися саме мотиваційних чинників, які 6 сприяли ефективнішій діяльності закладів охорони здоров'я. Як відомо, не лише матеріальні цінності $є$ мотиватором до ефективної роботи. Людині притаманне прагнення до самовдосконалення та самодостатності. Такі якості сприяють впевненості у своїх силах, а відтак і в успішності та кращих результатах роботи.

Тож, виходячи із даних міркувань, ми аналізували оцінку блоку «Процес розвитку працівника i навчання». Керувались альтернативною гіпотезою щодо потреби у можливостях професійного, культурного розвитку та подальшого навчання. У процесі дослідження виявили, що «Процес розвитку працівника і навчання» оцінений респондентами на $(8,1 \pm 2,7)$ бала (рис. 1). Така оцінка свідчить про те, що $\epsilon$ ще поле для удосконалення роботи щодо збільшення можливостей цієї мотиваційної складової, яка дозволить медсестрам мати більше можливостей для свого соціального зростання і отримувати більше задоволення від своєї роботи.

Тісно пов'язано із попередньою мотивацією поняття трудової етики. Ставлення до своїх обов'язків, адекватність розподілу праці та справедливість такого розподілу, ставлення до роботи в плані якості та відповідальності - це ті основні позиції, які при позитивній реалізації дають високу ефективність праці, i, як наслідок, створюють позитивний моральнопсихологічний клімат в організації. Перспективність діяльності, як можливість кар'єрного зростання, $\epsilon$ потужним моральним стимулом і дієвим мотивуючим чинником для максимальної віддачі працюючих [4]. Саме ці позиції лягли в основу оцінки блоку «Трудова етика і вмотивування» і яка становила при вивченні $(7,85 \pm 2,7)$ бала. Як бачимо, оцінка дещо вища середньої (рис. 1), але трохи далека від ідеалу. Дана оцінка сигналізує керівництву про певні недопрацювання в організації праці, що призводять до невисокого рівня задоволеності персоналом своєю діяльністю, і потребує певних заходів щодо налагодження ефективніших методів організації праці медпрацівників у закладах охорони здоров'я.

ще слабша позиція в організації роботи колективу в питаннях тайм-менеджменту. Блок «Усвідомлення часу, ставлення до часу і його використан- ня» оцінений середнім медичним персоналом у $(6,81 \pm 2,5)$ бала. Це одна з найнижчих кумулятивних оцінок складових корпоративної культури. Особливо необхідно приділити увагу питанням інтенсифікації праці та її нормуванню і доведенню до уваги співробітників не лише необхідності цього процесу, а і його реалістичності та відповідності нормам. Із попередніх досліджень відомі численні факти перевантаження медсестер паперовою роботою, кількістю маніпуляцій, доручення їм невластивих для середнього медичного персоналу функцій тощо. Такий дисбаланс між необхідністю та можливостями і призвів до такої низької оцінки середнім медичним персоналом даного блоку.

І два останні блоки досліджень були присвячені комфортності персоналу на їх робочому місці, що включали питання як взаємовідносин по горизонталі та вертикалі між людьми в колективі, так і умов їх роботи, зокрема традицій харчування тощо. Рівень «Взаємовідносини між людьми у Вашому колективі» був оцінений теж не на найвищому рівні - $(7,73 \pm 2,7)$ бала. Структурний аналіз цих відносин свідчить про потребу в закладах охорони здоров'я напрацювань з підвищення рівня культури взаємовідносин у колективі. Адже головною функцією культури є людинотворча, або гуманістична, функція, бо втрата духовного свідчить про занепад і культури, і організації, у якій вона проявляється [5].

Культура харчування $\epsilon$ складовою культури здоров'я людини. І заклади охорони здоров'я, логічно, що мали би бути тими пропагандистськими центрами саме здорових традицій харчування. Саме у проблемі харчування інтегровані здоров'я, етика, комфорт, добро і зло, знання та загадки тощо. Культурі харчування притаманні символічність, традиційність, значною мірою стереотипність та традиції поколінь, її характерними ознаками $є$ внутрішній запал і творчий імпульс. Культура харчування - явище соціальне, тому вона завжди репрезентує духовну сферу соціального організму. Саме, виходячи із цих трактувань і значення цього явища, ми у дослідження корпоративної культури закладів охорони здоров'я додали блок «Організація харчування співробітників», який включав як звички співробітників у царині харчування, так і традиції застільного святкування урочистостей. Всупереч нашій альтернативній гіпотезі ми отримали найнижчу оцінку $((5,97 \pm 2,4)$ бала) за вираження культури харчування у закладах охорони здоров'я. Дана оцінка свідчить 
про значні проблеми в культурі харчування, а також про слабке уявлення ії значущості у корпоративній культурі закладів. Тому на перспективу, керівництву закладів охорони здоров'я варто приділяти більше уваги саме цим питанням. Саме заклади охорони здоров'я та їх співробітники повинні бути взірцем пропаганди здорового способу життя, і культура харчування - це ядро цієї позиції.

Висновки. Для збільшення ефективності діяльності закладів охорони здоров'я основний акцент варто робити на підвищенні культури саме середнього медичного персоналу.

У закладах охорони здоров'я, зважаючи на важливість питань комунікації, слід більше уваги приділяти їх удосконаленню і знаходити мотиваційні чинники для середнього медичного персоналу з метою удосконалення та покращення. Оцінка блоку «Трудова етика і вмотивування» сигналізує керівництву про певні недопрацювання в організації праці, які призводять до невисокого рівня задоволеності

\section{СПИСОК ЛІТЕРАТУРИ}

1. Методика оценки психологической атмосферы в коллективе (по А. Ф. Фидлеру) [Электронный ресурс]. Режим доступа: https://vsetesti.ru/109/.

2. Бондаренко С. М. Імідж організації: сутність, зміст та основні етапи формування [Електронний ресурс] / С. М. Бондаренко, К. В. Ліфар. - Режим доступу : https://knutd.edu.ua/publications/pdf/TD/2014-2/ Bondarenko2015060410.pdf.

3. Варган С. Корпоративная этика: больше, чем просто этика [Электронный ресурс] / С. Варган. - Режим доступа : http://www.luxemag.ru/etiquette/6503.html. персоналом своєю діяльністю і потребує певних заходів щодо налагодження ефективніших методів організації праці медпрацівників у закладах охорони здоров'я.

Найбільше проблем у структурі корпоративної культури закладів охорони здоров'я виявилось при аналізі блоку «Організація харчування співробітників», оцінка якого була найнижчою, що свідчить про значні пробіли в культурі харчування, а також про слабке уявлення їі значущості у корпоративній культурі закладів. Тому на перспективу, керівництву закладів охорони здоров'я варто приділяти набагато більше уваги розвитку здорового способу життя персоналу і культурі харчування як основному компоненту.

Подальші наші дослідження будуть присвячені поглибленому вивченню елементів корпоративної культури в закладах охорони здоров'я, які потребуватимуть подальшого удосконалення.

4. Гаврилюк С. М. Ефективні технології мотивації персоналу / С. М. Гаврилюк // Актуальні проблеми управління персоналом та економіки праці : збірник матеріалів IV Всеукраїнської науково-практичної конференції молодих учених і студентів. - Житомир : ЖДТУ, 2015. - С. 44-47.

5. Горобець Н. М. Пропозиції щодо удосконалення моральної мотивації в системі управління персоналом підприємства [Електронний ресурс] / Н. М. Горобець. Режим доступу : http://nauka.kushnir.mk.ua/?p=73545. 